\title{
Utilization Of the Mendeley Application as Reference Manager For High School Teachers
}

\author{
Moh. Mahfud Effendi ${ }^{1}$, Reni Dwi Susanti ${ }^{2 *}$ \\ ${ }^{12}$ Program Studi Pendidikan Matematika, Universitas Muhammadiyah Malang \\ Corresponding Author: renidwi@umm.ac.id
}

\begin{abstract}
This study aims to describe how the Mendeley application is used in writing scientific papers by teacher representatives and to see how the effectiveness of using the Mendeley application as a References Manager. The type of research used is descriptive with a qualitative approach. Data collection was carried out by observation and questionnaires. The instruments used to retrieve data were the observation sheet and questionnaire sheet. Data analysis was carried out by reducing the data from observations and questionnaires, then the data from the reduction results were then presented in the form of tables and descriptions, which were then concluded with the results. The results showed that the Mendeley application could be used easily by teachers in compiling articles and the effectiveness of the response to using the Mendeley application as a Reference Manager also received a high percentage of $83 \%$. And the teacher's interest in using the Mendeley application is also high, namely $81 \%$. This is because the teacher said that Mendeley was very easy to use and up to date.
\end{abstract}

Key words: Mendeley, reference manager

\section{INTRODUCTION}

Educators are said to be one of the most important elements in learning (Aina et al., 2015). This is because the teacher is the mastermind in the classroom. Educators who manage all learning in the classroom. All learning scenarios are regulated by educators so that students become mature and ready to take part in learning.

Seeing the importance of an educator in learning activities, the government provides new policies in the world of education. The policy is intended to support creativity and develop the professionalism of an educator. One of the policies that are being discussed is the policy where educators must be able and must be able to produce scientific work.

Producing scientific work is currently the dream of all educators. Scientific work, can support the professionalism of an educator and become a benchmark for the progress of knowledge and technology of a nation (Marselina, 2018). Scientific work has various forms. Scientific works that are easy to organize are scientific works in the form of articles. The article is then published in a journal. An article is a series of research results or studies produced by an author. The results of the research or study can be used as a contribution to new knowledge for readers.

However, the problem that occurs today is that very few educators have the skills to write a scientific work, including in this case scientific articles. This is due to the weak writing skills of an educator. Writing is an activity to express ideas or ideas in the form of a description. However, the description must still follow the rules contained in the rules of writing an article or a scientific work.

The basic assumption that is feared by an educator in writing is that the writing or idea described is the wrong idea. So that assumption makes educators weak in writing. Educators fear that what is written is wrong or that something is taken from someone else's writing. In addition, it is also difficult for educators to get references or reading sources as a writing references. 
Mendeley is an application that can help educators in finding references or reading sources. With Mendeley, the author will easily get reading sources in the form of articles or books according to the theme to be studied. In addition, Mendeley also makes it easier for writers to quote and write a list of references or a list of references.

Previous research conducted by (Arta, 2018) on how to Article Writing Training for Publication in Scientific Journals to Increase Professionalism for Teachers in Kubuaddan District, Buleleng Regency which stated that the cause of educators in writing scientific papers was due to lack of knowledge and understanding in writing works. scientific literature, limited reading facilities, and the absence of journals or magazines in the area as well as the low motivation of educators in participating in scientific writing competitions. Another study by (Kurniadi, 2017) on Writing Student Scientific Papers With Media Word Processing Applications that generates ideas about word processing application media can help educators in producing scientific papers, this is because the results are effective.

SMA Islam Batu is one of the senior high schools in Batu City. SMA Islam Batu has qualified resources in the field of education. Based on the results of field observations in August 2019 at SMA Islam Batu. SMA Islam Batu has high hopes if some tutors or resources can provide new material or knowledge about writing scientific papers. And currently, there are no scientific articles produced by educators in high school. This is due to government policy that an educator is obliged to produce scientific work. Islamic Rock. In addition, there is also a weak motivation of educators in writing. With some of the background experienced by the school, mentoring and training in writing Scientific Articles at SMA Islam Batu assisted by Mendeley needs to be done.

\section{METHOD}

The type of research used in this research is descriptive with a qualitative approach. This study describes how to use the Mendeley application and see how effective it is in finding references for article preparation. The research was conducted at SMA Islam Batu. Effectiveness is seen from how the teacher's response and interest in using the Mendeley application.

Data collection techniques were carried out using observation and questionnaires. Observations were carried out using an observation sheet instrument which aims to see how the implementation of mentoring using the Mendeley application in the preparation of articles, then giving a questionnaire was carried out using a response and interest questionnaire instrument. The response questionnaire was used to see how the teacher responded by using the Mendeley application, then interest was used to see how the teacher's interest was in using the Mendeley application. The data obtained are then analyzed by reducing or selecting and sorting the results of observations and questionnaire sheets, then after being reduced the data is presented in the form of descriptions and tables which then concludes the results.

\section{RESULTS}

This research was conducted in September 2020. The research subjects were teachers at SMA Islam Batu. This study aims to see how the implementation of mentoring in the use of the Mendeley application as a reference manager and how the responses and interests of research subjects are carried out.

The activity began with a workshop attended by 11 teachers, then continued with mentoring at the next meeting. The mentoring activity was attended by 4 teachers who participated directly. The mentoring activity includes creating a Mendeley account via 
the web and installing Mendeley Desktop. Then proceed with Mendeley synchronization with Microsoft Word. Here are the steps starting from creating an account, installing Mendeley desktop to viewing for Microsoft Word that has Mendeley installed.

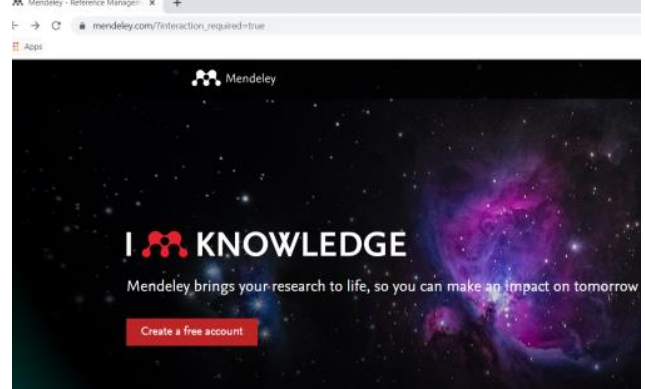

Figure1. Register Mendeley web Account

Figure 1 above is a view for opening the mendeley.com link for the first time. Then you can proceed with Create a Free Account by entering your email name and password and filling in your identity. By registering with Mendeley Web, this account can then be used to log in or install Mendeley Desktop. Like the screenshots below.

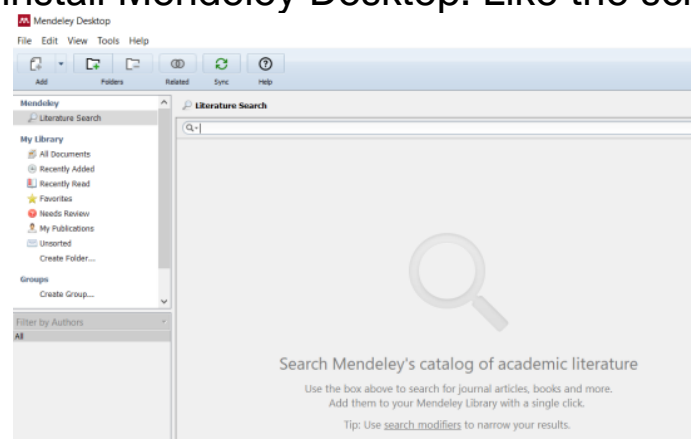

\section{Figure 2. Mendeley Desktop View}

The display in Figure 2 is the display on the Mendeley desktop, where the display can be used for writing quotes or references in Microsoft Word. However, before it can be used directly in Microsoft Word, the next step is to install or synchronize Microsoft word with the Mendeley application, the way to install is to select the Tool menu bar on the Mendeley desktop, then proceed by selecting Install Ms. Word Plugin, wait until the process is successful. If it is installed then on the Mendeley Desktop the display will be "Uninstall Ms. Word Plugin". As in picture 3

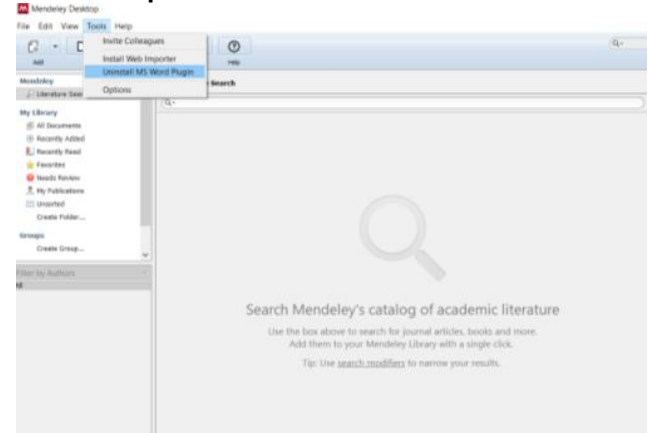

Figure 3. Install Mendeley Desktop with Microsoft Word. 
Figure 3 is a view after the Mendeley desktop is installed or synchronized with Microsoft Word which then on Microsoft Word will appear as Figure 4.

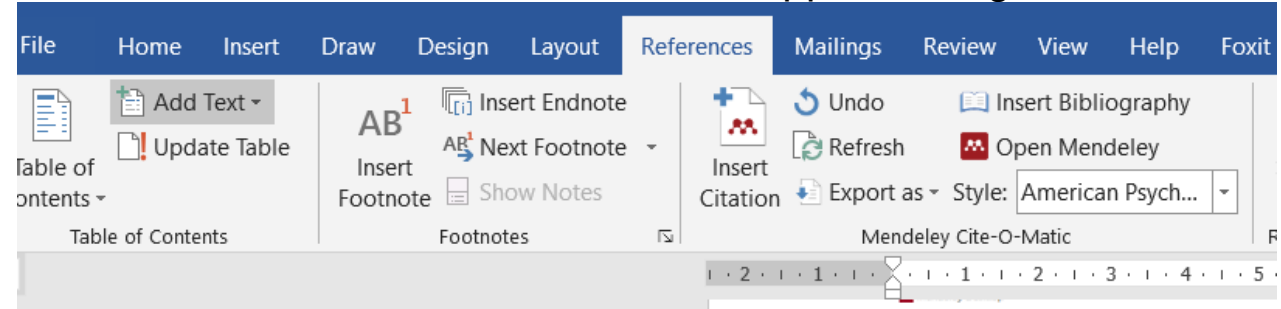

Figure 4. Mendeley Installed Microsoft Word.

Account creation and synchronization activities went smoothly and all followed well. However, before all accounts were created, the problem was that some of the teachers forgot their respective emails, so some created a new email first. After creating an account and installing the Mendeley application, it was continued with an explanation for the use of the Mendeley Web application and the Mendeley Desktop application. One of them is the use of Mendeley Web to find references or references. That is by clicking the search menu on Mendeley web and then typing the keywords to be searched, as shown in Figure 5.

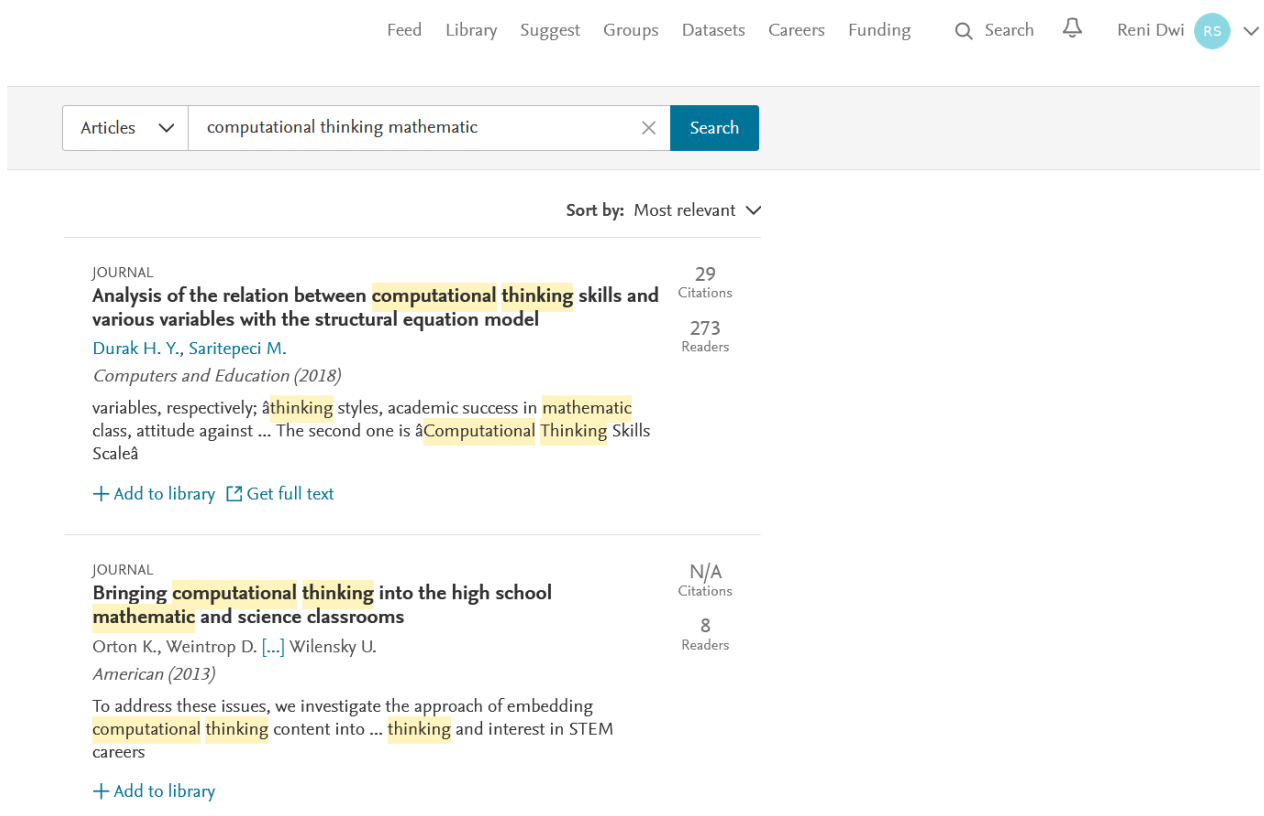

Figure 5. Finding References with Mendeley Web

Figure 5 shows how to find references using the Mendeley web. In this activity, the teachers participated enthusiastically and gained a lot of new knowledge because they would immediately encounter various articles in journals. So that a lot of new information was obtained by the workshop participants. In addition to the emphasis on using the Mendeley application for article preparation, this activity is also a step to teach workshop participants in finding new sources of information that can also be used as material for teaching references, for example, about the latest teaching theory or the latest learning media. This can also be seen from how the workshop participants' interest in implementing the use of the Mendeley application was distributed using a questionnaire. The results of the workshop participants' interest questionnaire are illustrated in the following table. 
Table 1. Results of Participants' Interest in using the Mendeley application

\begin{tabular}{llc}
\hline No & Aspect & Percentage (\%) \\
\hline 1 & Mendeley is easy to use & 80 \\
\hline 2 & Clarity of explanation for using the Mendeley application & 86 \\
\hline 3 & Menu functionality level on Mendeley app & 78 \\
\hline 4 & Mendeley helps get new information & 86 \\
\hline 5 & Mendeley encourages to add insight or information & 85 \\
\hline & Average & 83 \\
\hline
\end{tabular}

Table 1 shows that the average interest in using the Mendeley application is $83 \%$. The highest percentage on the aspect of clarity in explaining the use of the Mendeley application and Mendeley helping to get new information, which is $86 \%$. This interest can be seen from the mentoring activities and workshop activities, where for the clarity aspect of the explanation of the use of the Mendeley application, it is known when the participants are active and enthusiastic in listening and practicing on their own laptops. In addition, it can also be seen from several participants who immediately asked how it was used or how to use it and immediately asked when there was something that participants did not understand in the explanation. For the Mendeley aspect of helping to get new information, it can be seen when in the implementation of mentoring and workshops, participants are asked to write down the keywords to be searched for, in these activities participants do it and immediately see and read what they are looking for, even participants find and read new things which are new participants get and new participants read during the activity.

The lowest percentage is on the aspect of the menu functionality level in the Mendeley application, this aspect can be seen. When many participants asked what the difference was between Mendeley web and Mendeley desktop, then participants also asked about some of the functions of the menus or sub-menus on the Mendeley desktop. For Mendeley web, participants can immediately conclude that its use is to search for references directly by typing keywords, then selecting articles to be read and storing them in the library or adding them to the library.

In addition to the interest of the workshop participants, the next is the results for the responses of the workshop participants in using the Mendeley application. The results for these responses were obtained from a questionnaire given to the workshop participants. The results of the questionnaire for participant responses in using the Mendeley application are in table 2.

Table 2. Results of Participants' Responses in Using the Mendeley Application

\begin{tabular}{llc}
\hline No & Aspect & Percentage (\%) \\
\hline 1 & Having fun with the Mendeley app & 81 \\
\hline 2 & Active in workshop activities & 88 \\
\hline 3 & Interested in using the Mendeley app & 83 \\
\hline 4 & $\begin{array}{l}\text { Caution when explaining the use of the Mendeley } \\
\text { application }\end{array}$ & 85 \\
\hline & Average & 84,25 \\
\hline
\end{tabular}

Table 2 shows that the response of workshop participants in using the Mendeley application is 84.25. The percentage is also a high yield. The aspect of feeling happy can be known from the workshop participants using the Mendeley application and exploring for themselves what can be obtained from the Mendeley application by means of participants trying out how to use it. The next aspect is being active in workshop activities, this aspect is very clear. Workshop participants participated in training and 
mentoring activities from beginning to end and immediately asked questions when they felt confused about an explanation. The third aspect is interesting in using the Mendeley application, the percentage obtained is 83 . This aspect was also seen during mentoring activities and workshop activities, where participants revealed that it was the first time they recognized the Mendeley application, even participants said that by using the Mendeley application, they would immediately get references to the exact source and there are no more references to unclear sources or origins. The last aspect is the attention when explaining the Mendeley application, as well as being active in workshop activities, workshop participants are very active in following the explanations of the workshop presenters about the use of the Mendeley application.

\section{DISCUSSION}

In accordance with the description of the results of the study, it can be said that the introduction of the Mendeley application was well followed by workshop participants and was a new thing for workshop participants and it can be said that Mendeley helped workshop participants in finding something that was considered new and made it easier to find new references with clear sources. Participants acknowledged that Mendeley was very easy to use and very helpful. This result is also in line with the dedication carried out by (Pahmi et al., 2018) where in service it was stated that participants responded positively and very actively to the Mendeley application introduction activity, besides that participants also said that the training was very useful and helped them become good teachers. more productive to write more scientific papers using the Mendeley app. Research conducted by (Nurisani et al., 2019) also states that the reference manager application that is widely used today is the Mendeley application, this is because Mendeley is very easy to use.

\section{CONCLUSIONS AND RECOMMENDATIONS}

The description of the results and discussion stated that the use of the Mendeley application was well followed by all workshop participants. The application is very easy to introduce to workshop participants and workshop participants also participate in activities from beginning to end very well and very actively. This activity can also be seen by filling out interest questionnaires and workshop participants' responses to the use of the Mendeley application. The results of the interest questionnaire show an average of $83 \%$, where workshop participants will always use the Mendeley application, greetings to find new references because the articles on Mendeley are clearly sourced and there are many new things that workshop participants get. The response questionnaire got an average of $84.25 \%$. In accordance with the response, the workshop participants felt that the Mendeley application was very easy to use and did not require a long time in its application.

\section{ACKNOWLEDGMENTS}

The service team expressed their gratitude to DPPM UMM who had provided service funds so that this mentoring activity was carried out. In addition, the service team also thanked SMA Islam Batu for welcoming us during service activities. 


\section{REFERENCES}

Aina, M., H, B., SB, R., H, A., \& Sadikin, A. (2015). Pelatihan Penulisan Karya Tulis IImiah bagi Guru Guru SMA 8 Kota Jambi. Jurnal Pengabdian Pada Masyarakat, 30(3), 29-32.

Arta, K. S. (2018). Pelatihan Penulisan Artikel Untuk Publikasi Di Jurnal Ilmiah Untuk Meningkatkan Profesionalisme Bagi Guru-Guru Di Kecamatan Kubutambahan Kabupaten Buleleng. Acarya Pustaka, 5(2), 17-32. https://doi.org/10.23887/ap.v5i2.17412

Kurniadi, F. (2017). Penulisan Karya Tulis Ilmiah Mahasiswa Dengan Media Aplikasi Pengolah Kata. AKSIS: Jurnal Pendidikan Bahasa Dan Sastra Indonesia, 1(2), 267277. https://doi.org/10.21009/aksis.010208

Marselina, S. (2018). Peningkatan Keterampilan Menulis Karya IImiah Melalui Strategi Belajar Kooperatif Tipe Group Investigation Siswa Kelas XI Man I Kota Sungai Penuh. PENTAS: Jurnal IImiah Pendidikan Bahasa Dan Sastra Indonesia, 4(1), 1421.

Nurisani, R., Wulandari, E. R., \& Sundari, Y. (2019). Perilaku Penggunaan Aplikasi Sitasi Mahasiswa (Studi Kasus di Program Studi Pascasarjana Fikom Unpad 2018). Pustabiblia: Journal of Library and Information Science, 3(1). https://doi.org/10.18326/pustabiblia.v3i1.74-88

Pahmi, P., Ardiya, A., Syahfutra, W., Wibowo, A. P., Niah, S., \& Febtiningsih, P. (2018). PELATIHAN PENGGUNAAN MENDELEY UNTUK REFERENSI DALAM MENULIS KARYA ILMIAH BAGI GURU SMA HANDAYANI PEKANBARU. Jurnal Pengabdian UntukMu NegeRI, 2(2). https://doi.org/10.37859/jpumri.v2i2.849 